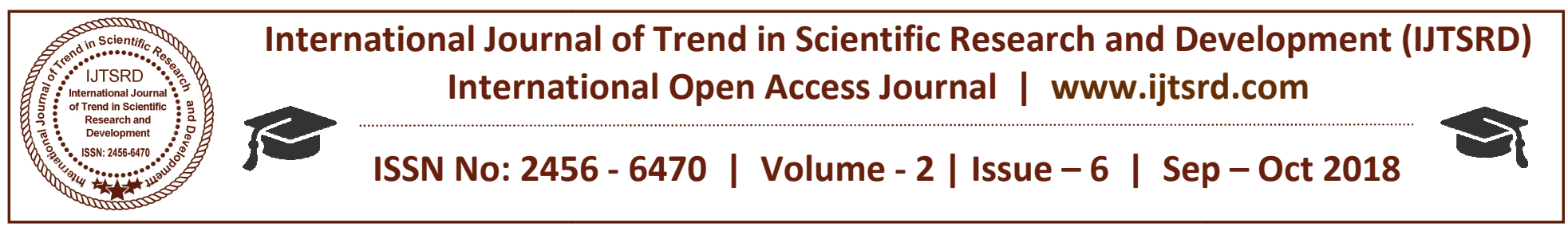

\title{
Nàgàrjuna's Reflection on Motion and Rest
}

\author{
Dr. Sudipta Chattopadhyay \\ Govt Approved Lecturer, Malda Women's College, Malda, West Bengal, India
}

\section{ABSTRACT}

Nagarjuna (C.150 - C.250) is considered to be one of the most famous thinkers of Indian Mahayana Buddhism, specially, in the Tibetan tradition and referred to as 'The Second Buddha'. Nagarjuna categorically repudiates the reality of motion as well as rest. $\mathrm{He}$ is known as the founder of the Madhyamika school of Buddhist thought, the school of the middle way. The middle way avoids both the extremes of eternalism as well as of nihilism. The main theory of Madhyamika is the doctrine of 'emptiness' or 'sunyata' which shows that all phenomena lack a permanent, unchanging and independent self-existence. Phenomena possess a conventional existence in which they appear to have a self-nature, although in reality they do not. This teaching is also found in the Four Noble Truths of Buddha. Just like all other Hindu philosophical schools, according to Buddha too, all sentient beings live in an infinite cycle of suffering which is caused by their ignorance concerning the true nature of phenomena. Beings do not realize the emptiness both of things as well as of mental phenomena and adopt attitudes of like and dislike, which creates the process of suffering. But it can be stopped if the appearance of phenomena and their true nature is realized. In 'Mulamadhyamakakarika', Nagarjuna tries to provide a philosophical rationale for the notion of 'emptiness', which is the key term in the 'Prajñaparamita Sutras', the earlier Mahayana literature. For Nagarjuna, Motion cannot be comprehended as identical with the mover for the mover and its activity (motion) cannot be distinguished then. If we have the conception of an inherent identity of the agent and its activity, the agent cannot really change its activity. A mover is identified with reference to motion and therefore, it would be a contradiction to say motion with mover. Again, 'motion without mover' also, is not accepted, if it is accepted, then, motion would be absolutely different from the mover. He argues that the mover cannot be motionless in himself apart from the motion, as it is a contradiction to say a mover without motion. It is also impossible to say that it has a motion other than the motion which inheres in it, because it implies two motions, for it is a mover that moves. Therefore, it is difficult to explain whether the mover can be understood with or without the motion. But without motion our usual life would be stopped. Sun, moon, stars, planets and other stars cannot move without motion. If motion is not accepted then astronomy would be in vein. Even we cannot speak and write without the movement of our vocabulary organs and that of fingers respectively. So, the existence of motion has to accept in usual life, in scientific research and in all other aspects of life.

\section{INTRODUCTION}

According to Nāgārjuna, it is impossible to give an intelligible account of motion, because to do so, is an attempt to make an analysis designed to cope with a certain limited practical problem apply far beyond its sphere of competence. Motion cannot be comprehended as identical with the mover for the mover and its activity (motion) cannot be distinguished then. If we have the conception of an inherent identity of the agent and its activity, the agent cannot really change its activity. A mover is identified with reference to motion and therefore, it would be a contradiction to say motion with mover. Again, 'motion without mover' also, is not accepted, if it is accepted, then, motion would be absolutely different from the mover. He argues that the mover cannot be motionless in himself apart from the motion, as it is a contradiction to say a mover without motion. It is also impossible to say that it has a motion other than the motion which inheres in it, because it implies two motions, for it is a mover that moves. Therefore, it is difficult to explain whether the mover can be understood with or without the motion. 
In fact, Nāgārjuna denies both, motion as well as rest. For him, space is divided mainly into two parts - the one is 'already traversed' and the other is 'yet to be traversed'. There is no space which is 'being traversed', because there, we have to admit two motions - motion in the space covered and motion in the moving body. Besides this, we have to admit two moving bodies, since it is not possible for the same body to be in two places at the same time. Not only that, when a body is at rest, before the beginning of the activity, motion does not occur. It is not possible to say that motion begins where it does not exist and therefore, motion cannot be thought in the space yet to come.

\section{DISCUSSION:}

Now, if we go through the 'Mūlamadhyamakakārikā', we find that Nāgārjuna devotes the second chapter of his book to point out the inherent contradiction of the concept of motion (gati). According to him, considered from every aspect, the notion of gati or motion cannot be explained. For him, "What has been moved, in the first instance, is not being moved. What has not been moved is also not being moved. Separated from what has been moved and has not been moved, present moving is not known.(Gatam na gamyate tāvad $\bigcirc$ agatam naiva gamyate/gatāgatavinirmuktam gamyamānam na gamyate.)"1

Let us clarify this argument with an example as given in the commentary 'Prasanyapadā' written 'by Candrakīrti. "In the time of walking, when we put a step, a portion of the track of that movement is already traversed by the front portion of the foot which should be called 'gata' or 'what is already traversed', that is to say, there is no motion in that portion. Again, the back portion of the foot must be called 'agata' or 'what is not yet traversed'. The portion of the track of the movement is not yet traversed by the back portion of the foot. Therefore, there is no motion there. Thus, in the time of walking, the so-called movement is not found anywhere. As a matter of fact, on a close scrutiny, there cannot be any movement. The concept of 'motion' must be regarded, therefore, as unreal.’2

It is to be kept in mind that the arguments of Nāgārjuna are directed against the Buddhist schools called 'Sarvāstitva Vāda'. The Sautrantikas and Vaibhāsikas belong to this school. According to them, an object is nothing but the collection of atoms only. It is different from the Vaiśesika view called 'Avayavi Vāda', viz., an object is something over and above the parts.

It might be objected however from the opponents' standpoint that "Where there is movement, there is motion. For which reason movement is in the present moving, and not either in the moved or in the not moved, for that reason motion is available in the present moving. (Cestā yatra gatis tatra gamyamāne ca sā yatah/na gate nāgate cestā gamyamāne gatis tatah.)"3

It is to be emphasised here that Nāgārjuna anticipates the opponent's objection. To this objection, Nāgārjuna says that this objection presupposes two movers which is absurd. To explain, to assert 'gamyamāne gati' or 'motion in the present moving', two motions have to be accepted for without motion there cannot be the act of present moving. The act of the present moving presupposes a mover. Again, the concept of 'motion' is intelligible if a mover is presupposed. As a matter of fact, if there were two motions, then, two movers also ought to be accepted.

Against this view, it might be objected that it may be granted for the sake of argument that if there are two motions there should not be any trouble. To accept two motions, it is not necessary to accept two movers. It can be treated as different actions of the same agent (mover). Do not we see a man walking and talking at the same time?

To this, it has been replied by Candrakirti that "the self-same agent may perform two types of different actions at the same moment. But it would not be logically possible to perform two actions of the same type simultaneously. It is difficult to admit that the self-same person, say, Devadatta is the agent of the action of moving as well as the 'motion' at the same time."4

Further, the Mādhyamika thinkers, mainly Nāgārjuna and Candrakîrti repudiate the reality of the mover (gantā) also. The term 'mover' only be understood with reference to motion and again, the term 'motion' only be understood with reference to the mover. So, there is obviously vicious circle and therefore, the concept of motion turns to be absolutely unintelligible. 
Again, the notion of mover itself is unintelligible further, for the following reason: $\mathrm{A}$ mover is understood only with reference to his motion. A person cannot be called a mover if he does not move. But Nāgārjuna points out that 'a mover moves' is nothing but a tautology bacause the word 'moves' becomes meaningful only in respect to his movement. For Nāgārjuna, we cannot say that 'Devadatta goes' or 'gantā gacchati', because, there is nothing other than 'gata' (what is already traversed) and 'agata' (what is not yet traversed). If we say that Devadatta gacchati or Devadatta moves, we have to say either gata moves or agata moves. But it is not acceptable. Therefore, all is void, what we see is apparently true but not absolutely true.

Against this view, it might be said that movement exists, as kāla (time) exists. The moment when a movement is going, is called the present. The moment when the movement ended, is called the past and the moment when a movement will occur, is called the future. Different agents like singers; cookers etc. perform their duties when needed. It is true in the case of a mover also. 'A person is a mover' does not imply that he always moves.

This argument, however, would be summarily rejected by the Mādhyamika thinkers as the very concept of 'time' or 'kāla' itself has been denied by them. It might be claimed that motion exists, because it has a beginning, e.g., Devadatta is standing and then, starting to walk. But for Nāgārjuna, as there is nothing like motion, there is no beginning and end of it. What is done, i.e., 'what is already traversed', has no beginning. There is nothing like 'being traversed' and therefore, has no beginning. Again, 'what is not yet traversed', has no motion and therefore, has no beginning and end. Therefore, the concept of 'motion' cannot be established by the concept of 'beginning and end'.

Again, Nāgārjuna's thesis cannot be repudiated by admitting that motion exists as rest exists. For Nāgārjuna, motion would exist if its opposite rest would exist. He denies rest. To explain, according to him, "it is not the mover or the non-mover (static) which is at rest and there is no third body which is at rest. The non-mover is not at rest, as it is already stationary and there cannot be two rests as this would involve two stationary bodies. As it is impossible for a mover to be without motion, it would be a contradiction to say that mover is at rest. Indeed, rest is not possible by cessation from motion, because cessation or stopping is an opposite activity of a mover. A mover cannot stop from the space 'already traversed' or 'yet to be traversed' or 'that which is being traversed'. Rest cannot begin when someone is at rest or is not at rest."5

In 'Mūlamadhyamakakārikā of Nāgārjuna: The Philosophy of the Middle Way', Kalupahana comments that "Prior to the commencement of movement, there is neither the present moving nor the moved from which the movement is initiated. How could there be a movement in the not moved?" 6

To explain, If a runner cannot get started in the present moment, it is not possible for him to get started forever, either because he has to transgress an infinite series of space-segments or because the atomic moment in which the movement should have started cannot be atomic for it has to consist of two moments, one in which the object is at rest and one in which it moves and also not in any following present moment.

Kalupahana also comments that "When the commencement of movement is not being perceived in any way, what is it that is discriminated as the moved, the present moving, or the not moved?"7

To explain, before an object can start to move in an atomic time-instant 'commencement of moving', it has to be in some state concerning motion and non-motion in the preceding moment. This cannot be the present moving, because this moment precedes it; it cannot be another 'moved', because the preceding moment has to be a state of non-motion for the object starts to move. The moment in which the movement should begin, is not perceptible as an atomic entity, because in this case it ought to be in two opposite states, namely, moving and not-moving. Nāgārjuna does not want to refute the possibility of perceiving motion as such but only in relation to a certain conception held, i.e., the infinite divisibility of moments of time. The thought of an unchanging, permanent substance in phenomena being one of the basic conceptions Nāgārjuna wants to refute. For him, a moved object cannot possess a substance remaining really the same throughout the course of motion. Nāgārjuna emphasizes further that if it should be granted for the sake of argument that motion exists, then, the question is: What is the relation between a mover and his motion? There may be two types of relation between them-'motion with 
mover' or 'motion without mover'. The first relation, i.e., 'motion with mover' is not accepted, if it is accepted, then, motion and mover would be identical and for Nāgārjuna, "If movement were to be identical with the mover, it would follow that there is identity of agent and action. (Yad eva gamanam gantā sa eva hi bhaved yadil ekībhāvah prasajyeta kartuh karmana eva ca.)"8

To explain, motion cannot be comprehended as identical with the mover for the mover (agent) and its activity (motion) cannot be distinguished then. If we have the conception of an inherent identity of the agent and its attribute (activity), the agent cannot really change its attribute. A mover is identified with reference to motion and therefore, it would be a contradiction to say motion with mover.

The second relation, i.e., 'motion without mover' also, is not accepted, if it is accepted, then, motion would be absolutely different from the mover. Nāgārjuna claims that "If the discrimination is made that the mover is different from motion, then there would be movement without a mover, and mover without movement.(Anya eva punar gantā gateh yadi vikalpyatel gamanam syād rter gantur gantā syād gamanād rte.)"9

To explain, it is not possible to admit the activity of 'motion' as absolutely different from the mover, for then, the 'movement', i.e., the action of moving cannot be predicted to the 'mover' as it is difficult to see how two absolutely different things can be predicated to each other. If we conceive the two as inherently different, we cannot explain the continuity of the one moving object. For Nāgārjuna, both, the mover and the motion do not exist, as they cannot be comprehended either as identical or as different from each other and so, for Nāgārjuna and other Mādhyamika thinkers, it is not possible to establish the reality of the concept of 'motion' by any means. It is found to be riddled with contradictions and it is nothing but 'śūnya'.

There is another equally strong assumption held by the Nyāya-Vaiśesika thinkers which is, viz., a thing is something over and above its parts. The discussion so far shows that according to Nāgārjuna, the concept of motion is unreal. But it might be emphasized here that the underlying assumption of Nāgārjuna's argument is, a thing is nothing but a cluster of atoms. This is the basic assumption of the Buddhist philosophers like
Sautrāntikas and Vaibhāsikas and it is really very difficult to re-establish the concept of motion if this assumption is accepted. It might be pointed out however that this assumption is accepted by all the Indian philosophers. In other words, a thing is entirely a new product which is different from its component atoms. If this assumption is accepted, then, the repudiator argument of Nāgārjuna mentioned in kārikā I, falls to be ground.

We find that the argument refuting the relationship of a mover and its motion has also logical defects. Mādhyamika argument can be refuted by introducing the Nyāya-Vaiśesika notion of Samavāya or Inherence. The movement is an action and the mover is an object. A predicate is related to its subject by the relation of Inherence (Samavāya). Here, the 'mover' is the agent and the action 'movement' is the predicate. It is obvious that they are not identical but the action is predicated to the object and these two are related by the relation of Inherence.

Thus, it is found that Nāgārjuna's thesis that 'motion is unreal', has no legs to stand upon. He argues that the mover cannot be motionless in himself apart from the motion, as it is a contradiction to say a mover without motion. It is also impossible to say that it has a motion other than the motion which inheres in it, because it implies two motions, for it is a mover that moves. Therefore, it is difficult to explain whether the mover can be understood with or without the motion. It is also difficult to say whether motion resides in a body which is itself independent of motion or not. Nāgārjuna states that "An existent mover does not carry out the movement in any of the three ways. Neither does a non-existent mover carry out the movement in any of the three ways. Nor does a person carry out the movement, both existent and nonexistent, in any of the three ways. Therefore, neither motion, nor the mover, nor the space to be moved is evident. (Sadbhūto gamanam gantā triprakāram na gacchat/nā sadbhūto'pi gamanam triprakāram sa gacchati/gamanam sadasadbhūtam triprakāram na gacchati/ tasmād gatiś ca gantavyam ca na vidyate.)"10

To explain, The 'three ways' are the assertions 'what has moved is being moved', 'what has not moved is being moved' and 'what has both moved and not moved is being moved'. The first implies a stable, substantial entity; the second a completely different, unconnected entity and the third implies both of these. 
All three of these are impossible and 'motion', 'mover' and the 'space to be moved'- all are unintelligible.

\section{CONCLUSION:}

In the language of physics, we can say that motion is a change in position of an object over time. In mathematics, motion is described in terms of displacements, distance, time, velocity, speed and acceleration. We cannot deny the existence of motion. In fact, we cannot deny the existence of motion. Our general sense asserts that any object in this universe stands with reference to space-time continūm. To be in motion, an object has to move from one place to another place, with reference to time. It indicates the change of its position, with reference to time.

In our times, we know from science that Earth, Sun and other planets and stars move on their own orbits. If motion is not accepted, then, it would not be possible and astronomy would become false. I have discussed earlier that NASA's Kepler mission has confirmed the first near-Earth-size planet, Kepler$452 \mathrm{~b}$ in the habitable zone around a Sun-like, G2-type star. This discovery and the introduction of 11 other new small habitable zone candidate planets mark another milestone in the journey to finding another Earth. Kepler-452b is larger than Earth, its distance from its parent star is 5 percent farther than the distance between the Earth and the Sun. Kepler- 452 is 6 billion years old, 1.5 billion years older than our sun. It has the same temperature, and is 20 percent brighter and has a diameter 10 percent larger. John Jenkins, Kepler data analysis lead at NASA's Ames Research Center in Moffett Field, California. For him, we can think of Kepler- $452 \mathrm{~b}$ as an older, bigger cousin to Earth. Kepler-452b is the smallest planet to date discovered orbiting in the habitable zone, the area around a star where liquid water could pool on the surface of an orbiting planet, of a G2-type star, like our Sun. Including this planet, the total number of confirmed planets become one thousand and thirty.

In practical life, human beings and other animals change places for various purposes, e.g., food, shelter, learning, etc. If there is no motion, how would it be possible for them to lead a normal life as without movement they cannot change their places. If there is no motion, then, we cannot speak with others. To talk to others the movement of our vocabulary organs, i.e., lips and tongue, has to accept and the movement indicates motion. Again to write, the movement of fingers also indicates motion. Hence, this discussion proves that motion has reality and it exists.

\section{REFERENCES:}

1. 'Mūlamadhyamakakārikā of Nāgārjuna: The Philosophy of the Middle Way': David J. Kalapuhana (Trs.): Motilal Banarsidass Publishers Pvt. Ltd.: Delhi: $1^{\text {st }}$ edn.1991:p.118

2. 'Prasanyapadā: The commentaryof Madhyamakaśāstra': Candrakīrti: Kārikā 1: The Mithila Institute of Post-graduate Studies and Research in Sanskrit Learning (publ.): Darbhanga: 1960: p.33.

3. 'Mūlamadhyamakakārikā of Nāgārjuna: The Philosophy of the Middle Way': David J. Kalapuhana (Trs.): Motilal Banarsidass Publishers Pvt. Ltd.: Delhi: $1^{\text {st }}$ edn.1991:p.119.

4. 'Prasanyapadā: The commentaryof Madhyamakaśāstra': Candrakīrti: Kārikā 1: The Mithila Institute of Post-graduate Studies and Research in Sanskrit Learning (publ.): Darbhanga: 1960: p.35.

5. 'Studies in Indian Thought': Collected Papers of Prof. T. R. V. Murti: Harold G. Coward (ed.): Motilal Banarsidass Publishers Pvt. Ltd.: $1^{\text {st }}$ edn.1983.p.155-156.

6. 'Mūlamadhyamakakārikā of Nāgārjuna: The Philosophy of the Middle Way': David J. Kalapuhana (Trs.): Motilal Banarsidass Publishers Pvt. Ltd.: Delhi: $1^{\text {st }}$ edn.1991:p.125.

7. Ibid: p. 125-126.

8. Ibid: p. 128.

9. Ibid: p. 129.

10. 10. Ibid: p. 130-131. 